\title{
Robotics and Mobile Devices to Reduce Digital Divide in a Rural Area of Costa Rica
}

\author{
Arnoldo Rodríguez \\ Universidad de Costa Rica \\ arnoldo.rodriguez@ucr.ac.cr
}

\begin{abstract}
Internet and mobile devices allow students from schools, high schools and colleges to share their knowledge and help each other in their learning process. This is the case of a two-year project carried out in Turrialba, a town located in the Caribbean area of Costa Rica, in Central America. To overcome geographical difficulties and age differences cell phones were used by the students to support their peers on theoretical and practical issues related to planning and building small robots. The project also intended to test specific teaching strategies among students from different educational backgrounds in an attempt to identify approaches that could help students develop skills related to robotics, as well as in other complementary areas.
\end{abstract}

\section{Introduction}

The main focus of this project is the implementation of strategies in the learning of robotics as an innovative teaching method for grammar school, high school and college students. Even though this project intended to test certain teaching strategies that help students develop skills related to robotics, the use of mobile devices was also an important component in the process of learning new technologies. Students could use the devices not only to improve technical abilities, but also to develop social skills in an environment of collaborative learning. A specific goal was to verify if a particular combination of teaching strategies improves both social and robotics skills or just one of them.

Teaching robotics to young people frequently implies a constructivist approach which emphasizes "learning by doing" as the main teaching strategy [1]. In addition to this approach, other strategies were also implemented; for instance, the "learning by teaching" strategy. This particular method had great relevance in the development of this project. The most used teaching methods allow students to receive information, follow instructions from a tutor, reuse examples, and apply their creativity to build robots. Our teaching methods helped students to enhance their technical and social skills by teaching robotics to other students by means of mobile calls and short messages, something that is not easily accomplished by other methodologies.

\section{Scope}

This paper focuses on the experience and findings of a two-year project that intended to promote robotics in the schools of Turrialba, a rural town located in the Caribbean area of Costa Rica, in Central America. This region is located 65 kilometers East from San José, the capital of the country. An important part of the territory (Turrialba) belongs to Indigenous communities and natural parks.

The use of robotics to improve the students' digital literacy constituted a way of making people aware of these topics, and especially in these rural areas where robotics was unknown. Robots or robotic related materials had never been used in the educational system of Turrialba before this project started. Consequently, this is a first step to introduce robotics to a community with around 70,000 inhabitants, where almost 20,000 are grammar school, high school and college students [2]. Those students attend 170 institutions distributed in $1,664.57 \mathrm{~km} 2$. Almost $50 \%$ of the schools have a teacher with no more than 30 pupils, who live in isolated communities, including some Indigenous towns with no electricity [3]. Currently, the literacy rate is $96 \%$ and people attend at least 8 years of school in Turrialba, as an average. Regarding the access to telecom services, $82 \%$ of the population have cell phones, $53 \%$ of households have a landline telephone, $38 \%$ of households have computers and $24 \%$ of them have Internet connections [2].

This project started as a way of spreading information about robotics and also as an attempt to look for a conceptual framework in regard to teaching robotics. Limited resources were available; hence, no more than 40 students and teachers from five grammar schools and three high schools were included in this study. The robotics project was funded by the Universidad de Costa Rica and CONARE, a council of public universities of Costa Rica.

There is extensive research related to the constructivist framework and the role of robotics as a 
cognitive bridge between theoretical aspects of education and concrete experience [1]. Having said that, the focus of our project was not to study the role or the importance of constructivism/constructionism. Instead, we paid attention to the resources and strategies that can be applied to relate theory and practice in a way that let students build their own knowledge about robotics.

Usually, teaching robotics entails the participation of learners in robot tournaments as a mechanism to increase students' motivation and as a way to evaluate their progress. However, our project focused on collaborative processes and sharing knowledge in lieu of contests, as other projects did. The participants in the project were not evaluated with formal methods (pre-test, post-test); but instead we checked the progress of learners while building robots to improve versions iteratively. When a student faced a barrier to continue, she asked the instructor or peers for help to solve the problem. Help was given face to face or via Short Message Service (SMS). Therefore, robots were viewed as instructional media for an extracurricular activity that was not integrated into the classroom.

\subsection{Problem}

An important problem faced by the project was overcoming geographical barriers, difficulties to have access to Internet and robots, and age differences related to promoting robotics both at grammar schools and high schools. Consequently, it was necessary to find the resources and a methodology that helped learners to acquire the skills for building robots as well as developing abilities in collaborative work.

\subsection{Purpose}

The general purpose was to expand the knowledge about robotics as a way to improve the digital literacy and to reduce digital gaps in grammar schools and high schools from rural areas in Costa Rica. This effort promoted the diffusion of an innovation, namely robotics, by applying an informal learning process without formal evaluation [4].

Our general objective was to identify and apply a methodology that provided some knowledge about robotics to grammar school and high school students from rural communities in Costa Rica. Then, the project aimed to test selected teaching strategies among students from different schools to determine which strategies are better suited to help learners develop skills related to robotics, as well as abilities in complementary social areas. Skills about robotics included planning, building, and programming robots and the complementary areas were collaborative work, communications and social networks.
In order to achieve the general objective, the project tried to answer the following questions:

Which resources and methods are best suited to promote robotics in educational institutions of rural areas?

Which strategies allow students to develop skills for building and programming robots in a shorter period?

Which strategies best help students to master building and programming robots?

Which strategies best integrate knowledge and abilities about robotics, collaborative work, communications, planning, and social networks?

In the next sections we discuss possible solutions, answers to the questions above, the evolution of the project, other research related to our subject, evaluations and conclusions.

\section{Background literature}

Since the diffusion of robotics as an innovation for education was the north of this project, concepts related to teaching strategies, skills for problemsolving, managing cognitive load and learning by using mobile devices to support collaborative learning were particularly important.

\subsection{Teaching Strategies}

A teaching process implies pedagogical strategies or teaching strategies that refer to the methods of instruction. Pedagogical strategies include teaching events to help the learner follow her/his learning process. Learning by example, learning by storytelling, learning by doing, learning by problem solving, learning by games, learning by analogy are a group of discovery strategies, where the learner infers rules from experiments where she is involved in manipulating devices or following procedures.

Among pedagogical strategies, "teach to others", "learning by doing" and discussion groups allow students to assimilate contents. Interaction between learners impacts individual and group behavior because having access to others opinions and help "can develop individual reflection on and analysis of various problem factors" [5]. In particular, problemsolving activities not only involve aspects related to the complexity of the problem itself but also those related to the personality traits of students. This reason led the project to apply learning by teaching as an important teaching strategy to solve design and programming problems.

\subsection{Enhanced Expertise}

In addition to the teaching strategies applied in the project, a manner to help students to evolve from beginners to intermediate learners was taking into 
account that freeing working memory or short-term memory is another important aspect for learning [6][7], because working memory has a limited capacity to deal with novel information. Every time a learner masters a type of knowledge or a model of robot, her working memory is free to acquire more complex concepts and skills in an iterative process [6]. As a result, the learner acquires new knowledge step by step and chunk by chunk in a process that includes feedback from the instructor and other learners, correction of errors, and solving problems with an increasing level of difficulty. Then, a learner acquires a simple concept and, iteratively, she learns more complex skills until acquiring an intermediate or higher level of expertise. According to Cognitive Load Theory (CLT) the use of examples also helps to reduce the cognitive load of learners while they are learning new contents [8]. CLT proposes providing problems with an appropriate difficulty level, in a repetitive process that includes feedback, the opportunity to correct errors and, gradually, solving problems with an increasing level of difficulty.

The teaching/learning process helps the learner go from novice to expert in five phases that let a learner pass through as she progresses: novice, beginner, competence, proficiency and expertise. In each phase, the learner performs certain activities intended to achieve some skills: receive and remember; imitate and apply; select and decide; understand and design; recognize and master [9]. In addition, these phases define the skills that a learner can develop: skills to deal with free-context situations, skills to act in context-sensitive conditions, skills for problem solving, skills to recognize patterns, and skills for managing complex situations. This approach is useful for gradually teaching robotics and also for adapting support to students as they progress and accumulate experience in building and programing robots. As the learner improves her knowledge, she also develops more responsibility, experience and expertise. Thus, students did not limit themselves to receive and remember information because they also were able to imitate and apply examples and rules. Advanced learners improved their knowledge and skills to design new and different robots and programs, achieving competence and proficiency levels.

In this case, other concepts associated with getting expertise are mobile learning and ubiquitous learning [10]. Mobile learning (m-learning) implies building knowledge in different contexts and types of activities with the support of mobile devices. Ubiquitous learning (u-learning) adapts e-learning and m-learning to anywhere and many disciplines [11]. In fact, students in a laboratory on an urban setting can interact with learners in another place nearby a cane plantation, at the same time [12]. They can also blend (b-learning) different teaching/learning strategies, as well as media, online and face-to-face interaction.

\section{Related work}

In general, it is not common to find projects that integrate robotics, teaching strategies and mobile communications. However, [13] research involving undergraduate students as "mentors" of younger learners who attended a summer program is close to our project. Some differences between the two projects include the time of the experiences, the number of participants and the use of mobile devices that were not as extended in 2004 as in 2010.

In [14], learning by design and the integration of learners from kindergarten to university are studied. Additionally, [15] report about the roles of robotics to support teaching different subjects, with Saya, a robot, playing the role of companion or teacher agent [15]. Other projects related to ours refer to robotics as a medium to attract high school students to science, technology, engineering, and mathematics [16][17]; an additional initiative focuses on improving digital literacy using robotics [18]; the roles that robots can play and the methodologies supporting teachers and students have also received attention from researchers [1][15][16][19]. More detailed, [18] and [19] report different phases or stages to progress learning about robotics that include visualization, simulation, building robots and creation of new models. In addition, [16] refers to Bloom's taxonomy and the links with direct instruction, problem/inquiry-based learning and project-based learning.

\section{Solutions}

The approach of this project included traditional activities and other ones that aimed to integrate technical aspects of robotics to skills related to collaboration and to group or social generation of knowledge.

\subsection{Strategies}

While learning robotics, students usually receive information, follow instructions from a tutor, reuse examples, and apply their creativity to build robots; but the teaching methods commonly used do not help students to improve their technical and social skills by teaching robotics to other students, as was done in this case. Learners in the project performed three activities throughout two years:

1. Following a tutorial. The students had access to a computer-based tutorial including step by step instructions, 3D graphics and video. As a complementary resource, an instructor was available to support learners. 
2. Creation of models by means of free exploration. The students participated in sessions to build robots from scratch on their own, in collaboration with other learners and with the support of some mentors.

3. Meetings, demonstrations and workshops. After acquiring proficiency on assembling and programming basic robots, some students traveled to other communities to share their experience with other students and teachers.

Accordingly, those activities were intended to test the following teaching strategies:

- Learning by example while students follow a computer-based tutor with the complementary support of a human instructor.

- Learning by doing new models of robots with the support of a human instructor.

- Learning by teaching robotics to other learners.

We did not identify and apply a particular methodology to support the students in the learning of robotics. Instead, a mix of teaching strategies was used. The strategy that best help students master building and programming robots according to our experience in this project was "learning by teaching" [20]. This was a main teaching strategy intended to help students improve their technical and social skills by teaching robotics to other students. This strategy was very useful when advanced learners met students from other educational institutions to teach them the first steps about robotics. Other complementary teaching strategies were also applied, such as learning by doing and learning by example [21].

Learning by doing is a strategy where the student can create her/his own knowledge and this project applied learning by doing and learning by teaching. Students who were formally trained in building and programming basic robots became skilled in robotics after a discovery and learning period. Then, they were asked to provide support and guidance to novice learners engaged in learning by doing. It was an intermediate strategy between discovery learning and guided learning that allowed novice and advanced learners to improve their abilities in robotics and social relationships [22].

Most of these advanced learners taught basic robotics not only to students from grammar schools and high schools but also to teachers, by means of oral presentations. Indeed, Fig. 1 shows two of the students explaining basic robotics to high school teachers during a training activity at the University campus in Turrialba. Also, three of the skilled learners were interviewed on a radio talk show of the University of Costa Rica, the leading university in the country.

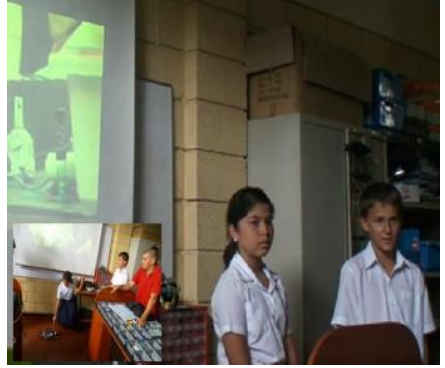

Figure 1. Advanced learners explained basic robotics to teachers in a training session

\subsection{Experience}

Students who received a formal training with learning by example and following tutorials developed technical skills about planning, building and programming robots and they created working models sooner than students who learnt by discovering first, in a more informal process. After a formal training (one term) of learning by example with instructors' support, the students of this first group preferred to work alone to enhance their skills with a learning by doing strategy and discovering new ways using their creativity.

In their second term in the project, these boys continued their routine but new participants asked for their help. Instructors also pushed the old group to support novice students as a way to improve selfconfidence and theoretical and practical abilities. The response of skilled students was positive, but they preferred to explore alone and very seriously, most of the time. One of these students prepared a model for a science and technology contest in his school. He spent additional time to develop a robot, working alone, and was the only one with a robot in the tournament.

These students were a small group (only six boys, 11-12 years old) from a public school located in the university campus. They were used to visit the laboratory frequently. They were also skilled using computers and liked to spend free time, in the afternoon after school time, building robots under instructors' guidance without a teacher of their school to support them. Their school teacher was concerned because girls of the same classroom did not want to participate in the project.

On the other hand, a group with more girls than boys from a private school started six months later, supervised by their computer teacher and the project instructors. Instead of receiving a previous formal training of learning by example and following a tutorial, this group began discovering how to build robots learning by doing, step by step, assembling, making mistakes, reassembling models for a long time before learning to program robots. The learning process was more collaborative, with more communication between students and more 
difficulties for learners because the lack of initial instructions. Usually, when a student solved a problem, the instructor asked her to teach the group. This method was challenging for those students because they were invited to explain their discoveries in front of the group. At the beginning, only a boy liked to show his progress, but after some weeks two girls started with demonstrations of their work and one of them also became more self confident and developed strong communication skills along the following months.

After a term of slow progress, this group became more and more skilled, not only planning and building robots but also programming them. Finally, these students were able to teach theory and practice of basic robotics to high school teachers and students, during training sessions developed in the university campus or in visits to communities. This kind of activities reinforced the group's skills about robotics and the students' abilities to share and communicate knowledge. Girls played an important role in this experience because they showed skills to get empathy from other students.

\subsection{Sharing}

Creating social networks to support the diffusion of robotics entailed linking students and the original planning called to do so by using face to face synchronous communication in a laboratory and by means of a Web site (e-learning and asynchronous communication). However, technological barriers to access Internet from the laboratory, the schools, and houses of the students became a difficulty for using social networks as a mechanism to share resources and knowledge. The laboratory in the University had a broadband connection to Internet, but the engineers on charge of technical support did not connect all computers to Internet alleging security reasons. Wireless broadband were also available but students did not have their own equipment to take advantage of the service. Unfortunately, a good resource for teaching and learning was not useful because of a technical policy in the university.

Facing this type of first order gap related to physical or material access [23], students started sending text messages and, although less frequently, images by cell phones to support each other when some of them were building or programming robots in the laboratory and other were at the school or at home. In that way, the laboratory experience evolved to a blended (sometime ubiquitous) learning process in which advanced students reinforced their learning by teaching other learners about theoretical and practical issues.

At the beginning of the project, using mobile devices as a media for the teaching/learning process was not planned because the university did not fund cell phones. However, some students had cheap devices and sending text messages was affordable because the Costa Rican government provides subsidies to keep SMS tariffs low for everybody. Cell calls and mobile access to Internet were not as cheap for children and teenagers. Fig. 2 shows a model that encompasses different components of the project.

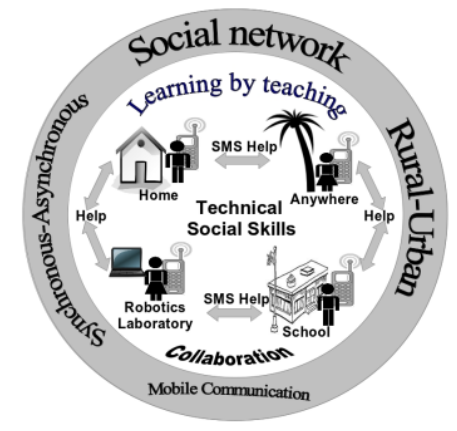

Figure 2. Different components of the project supported the development of technical and social skills

\subsection{Diffusion}

After some visits to other educative institution, newcomers engaged in the project and both they and the previous participants used SMS of their cellular phones to exchange help about technical aspects. A small virtual network of social relationships emerged after face to face meetings as a kind of informal community of knowledge building [24].

Some students sent SMS to other ones in a same city (Turrialba, headquarter of the project), but also to Pejibaye and Tucurrique, two communities separated by a 90 minutes bus trip from the laboratory at the University. The connection between students from the three communities began when instructors and students of Turrialba visited two high schools in Pejibaye and Tucurrique. After the initial meeting, students of the three locations met sometimes (face to face) in the laboratory and sometimes communicated by SMS in a virtual and mobile social network. E-mail was not useful because cell phones are more accessible than computers and Internet in rural areas of Costa Rica [2]. In most schools, students only have access to Internet when they attend courses in a computer laboratory.

Because mobile devices are different and have different limitations [25][26], some students did not have direct access to shared contents but they saw materials together around a single device or passing around devices with different contents, not only in the laboratory but also at the school. The integration of students coming from different institutions and levels of study was not difficult. For example, there were several instances of learners from high schools 
requiring support from grammar school students who were advanced participants.

\subsection{Division}

Another side of this story is that two additional groups of learners faced troubles and ended up quitting the project. A group of six girls and boys (fifth grade) was very playful, undisciplined and focused more on building robots than programming them. Only two girls tried to create working models but their progress was very slow because they changed models continuously, every time a difficulty appeared. This group belonged to the same school were the very serious boys described above studied.

An additional group entered early in the project and quickly left. No progress was possible in this case due to digital divide causes. Girls from a school located in a poor community, near to the dump of the city, had not had frequent contact with small plastic pieces such as those of the robotic kits used in the project. However, they were pleased to manipulate plastic pieces (Lego bricks) and began building basic robots, following examples of a printed guide with simple and clear graphics as [1]. Instructors knew the girls were not used to manipulate computers and the goal was to support and encourage the learners to enhance their technological literacy by means of visual or iconic programming. Usually, girls face troubles to learn programming and take computer science or engineering related careers at higher levels of education [27].

After a few sessions, the girls gave up. Finally, the group moved to other activity that included playing chess and taking basic computer lessons (Edubuntu) to improve digital literacy. This transitional activity let learners pass from manipulating real chess pieces to planning and playing games in a computer. They preferred to continue with chess and computer classes until the project finished.

Schools located in poor and isolated rural communities face digital divides: almost $15 \%$ of the 138 grammar schools in Turrialba did not have electricity when this project began. According to [30], more than 100 schools did not have Internet access and in 90 of those schools students had neither Internet nor computers. Indeed, 50 schools reported they needed a total of 500 computers for students, at least.

In addition to the digital divide, schools in Turrialba also faced other important problems related to infrastructure. By 2009, 50 schools were in need of classrooms, libraries, desks, chairs, blackboards, toilets, and even drinking water in some cases [30]. Thus, the digital divide became another gap that separates this region from the more developed central areas of Costa Rica and from the social and economic conditions of industrialized countries, for instance.

\section{Context}

Costa Rica has developed an Educational Technology Program (ETP) since 1987 by training teachers, building computer laboratories and teaching computer topics, included robotics, both in grammar schools and high schools. This is a collaborative effort of the Ministry of Education and a private organization (Omar Dengo Foundation) [28]. In Turrialba, this program covered 21 primary schools and high schools of around 170 educational institutions in total. Approximately, $40 \%$ of the students in grammar schools and 60\% in high school were covered in the area [29]. However, robotics was not included in the syllabus followed in Turrialba at the start of our project. According to [29], just 1533 students of a total of 472,788 covered by ETP were involved in educational robotics in Costa Rica in 2010. By that year, more than 800,000 students were enrolled in Costa Rican schools. Therefore, robotics was not an important activity of ETP.

A more critical problem was that only 21 out of hundreds of teachers working in grammar schools and high schools of Turrialba were trained on Information and Communication Technologies (ICT) when this project started. There were thousands of students but only a small number of teachers was trained to apply ICT for teaching [31].

In 2009, the Atlantic Branch of the University of Costa Rica, located in Turrialba, opened a Bachelor's degree program to teach educational computing and a robotics course was included. Consequently, a computer laboratory was created and robotics kits were bought with funds of a council of public universities (CONARE). The University of Costa Rica assigned additional funds for our initiative, a project intended to use kits and a laboratory in the diffusion of robotics as an innovation for education in the region.

A first step was to train college students as instructors of robotics. These instructors were students of the educational computing program and they were programmers interested on robotics who became involved in the project. They followed a learning process that included learning by example, learning by doing and collaboration. After a term of training, instructors received six students from a grammar school located in the university campus and another group from a school located in an urban sector far from the campus. During the following terms more students joined and the university bought more equipment. A Web site to share digital materials, tips and links to Internet resources was created but, unfortunately, connection to Internet was not always available in the laboratory or at the students' houses. That was one of the main reasons 
behind the adoption of SMS as a complementary medium of communication.

This "club" of robotics was created to let students to enjoy free time after school by approaching to robots. Consequently, participation was free and students could not practice with kits when they had to prepare for school tests. However, despite the importance of their formal studies, some of the participants had to travel for 90 minutes from their communities to the university campus and spent another 90 minutes to go back, one day per week. The travel included taking a bus, drop off the bus, walk across a small bridge to pass a river and take yet another bus, because the bridge was in bad shape and could not be crossed by buses. In Fig. 3 high school students build a robot in the laboratory at the university campus.

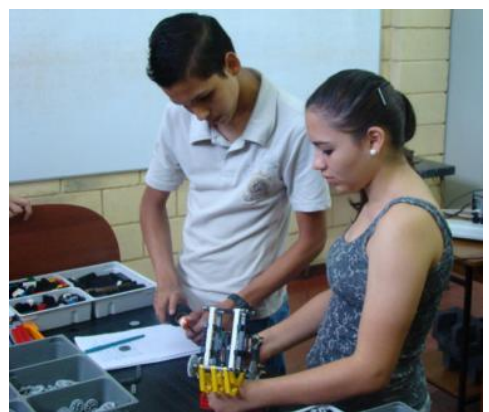

Figure 3. Students from rural high schools were trained on basic robotics

\section{Evaluations}

This project was a small-scale qualitative process aimed to disseminate information about robotics that lasted two years and at the end of each period evaluations were developed using printed surveys. Participants expressed their level of satisfaction with the instructors, teaching materials, and methods applied, and they were also asked about their recommendations to improve the activities. Additional data about the progress of the project were also collected by means of interviews to participants, direct observation of learners and instructors' field notes. In general terms, participants marked with "good" and "very good" most of the indicators of quality of the process. A minority of learners was pleased to participate in a project related to their future interests as students and workers. Two students expressed that this experience with robotics was important because they wanted to study engineering and design. Most participants did not link the project with long term plans, but they found the process helpful for activities in their schools.

After a two year project, around 40 students from eight grammar schools and high schools, six college students and a small group of teachers had participated in demonstrations and workshops about basic robotics. Fig. 4 shows teachers in a training session.

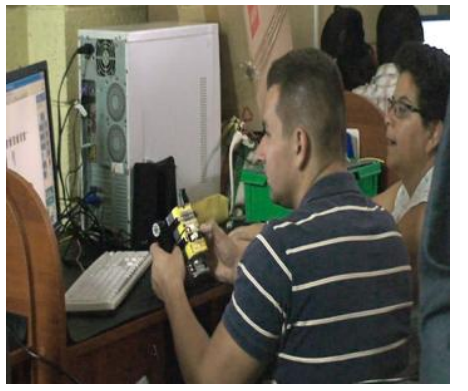

Figure 4. The project also included training for teachers

Unfortunately, only a school followed up the "robotics club" with an increased number of participants, in Turrialba. Furthermore, an additional classroom and instructors are required now. In Fig. 5, students of a new group of learners are showed building robots in 2013 .

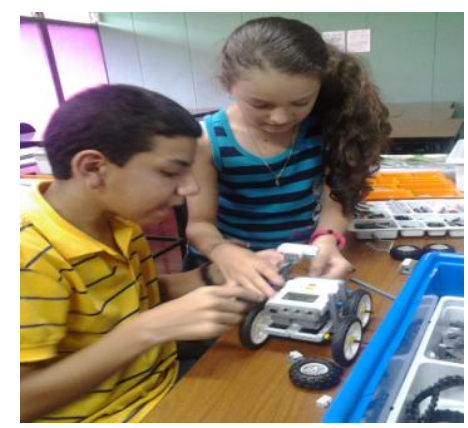

Figure 5. New students required an additional classroom in 2013

In collaboration with another public university, the University of Costa Rica is developing a similar project in other communities away from Turrialba. A private organization (Quirós \& Tanzi Foundation) developing a One Laptop Per Child (OLPC) program with the Ministry of Education in Costa Rica introduced robotics in three grammar schools of Turrialba [32]. A group of these students had an important participation in a national robotics contest under the supervision of a former instructor of the project. Another local private school hired an instructor who was partially trained in our project and this institution also started a robotics program. The impact of the project was positive because people had their first encounter with robots.

\section{Conclusions}

As a result of this experience, we have integrated parts of some guides and methods for promoting robotics. The mix of different methods includes teaching strategies in a small social network based 
on mobile devices and short messages service (SMS). Discovery learning was the best strategy to help students master building and programming robots, but learning by teaching let students integrate knowledge about robotics and social skills. The lack of infrastructure to access Internet was a barrier to use social networks and Web sites; then, instead of giving up, students switched to SMS. This is a paradox because, on one hand, a developing country does not offer easy access to Internet and, on the other hand, the same country keeps SMS tariffs cheap and learners profit from this "advantage".

At the beginning, robotics was a taboo theme for many students but it became more appealing during the second year and some parents also became interested. In some opportunities, parents even paid for transport to visit schools and high schools if University funds were not available.

An important lesson learned is shifting from the vision of a pilot project to a strategic thinking of education related to economic and social growth. Many experts on educational computing are concerned about constructivism and other "pedagogical aspects related to ICT, paying less attention to the relationship between education and social and economic development, especially in rural zones" [33]. Robotics is an appealing activity linked to artificial intelligence that can blur the view of academics, moving them away from the perspective of the future digital literacy, employment and income of current children and teenagers ten years forward, when they will be young workers.

\section{Acknowledgements}

This project was supported by the Universidad de Costa Rica and the Consejo Nacional de Rectores de Costa Rica. The author thanks Ms. Xinia Delgado, M.Ed., and Ms. Kathia Quirós, M.Ed., for their contributions to the project, and Mr. Jimmy Nájera, a volunteer who helps children of poor communities to improve their digital literacy.

\section{References}

[1] Bilotta, E., Gabriele, L., R. Servidio, and Tavernise, A., 'Edutainment robotics as learning tool', (2009), in Z. Pan, A. Cheok, W. Müller, and M. Chang (Eds.), Transactions on Edutainment III, Lecture Notes in Computer Science 5940, pp. 25-35.

[2] Instituto Nacional de Estadística y Censos (INEC), (2013), 'Indicadores cantonales, Censos Nacionales de Población y Vivienda 2000 y 2011 Cartago'; http://www.inec.go.cr/A/MS/Censos/Censo\%202011/SIM/ C0/05.\%20Indicadores\%20cantonales\%20Cartago/Indicad ores\%20Cantonales.pdf (12 December 2013).
[3] Ministerio de Educación Pública, (2010), Nómina de centros educativos, clasificados por dirección regional y circuito, Costa Rica.

[4] Rogers, E., (2003), Diffusion of innovations, Fifth edition, Free Press, United States.

[5] Spector, J., (2008), 'Complex domain learning', in H. Adelsberger, Kinshuk, J. Pawlowski, and D. Sampson (Eds.), 'Handbook on information technologies for education and training', pp 261-275.

[6] Lin, T. and Kinshuk, (2004), 'Adaptive techniques for supporting working memory capacity', in Proceedings of the International Conference on Computers in Education (ICCE2004), Australia, pp. 7871-792.

[7] Moreno, R., (2004), 'Decreasing cognitive load for novice students: effects of explanatory versus corrective feedback in discovery-based multimedia', Instructional Science, Vol. 32, Netherlands, pp. 99-113.

[8] Sweller, J., (1988), 'Cognitive load during problem solving: effects on learning', Cognitive Science, Vol. 12, pp. 257-285.

[9] Payr, S., (2003), 'The Virtual University's faculty: An overview of educational agents', Applied artificial intelligence, Vol. 17, Germany, pp. 1-19.

[10] Chang, M., Wu, S. and Heh, J., (2008), 'Making the real world as a game world to learners by applying gamebased learning scenes into ubiquitous learning environment', in Z. Pan, A. Cheok, W. Müller, A. El Rhalibi (Eds.): Transactions on Edutainment I. Lecture Notes in Computer Science 5080, pp. 261- 277.

[11] Liu, C., Wu, S., Chang, M. and Heh, J., (2008), 'Guiding students to do remedial learning in school campus with learing objects' spatial relations', in Proceedings of workshop on ubiquitous learning models for $\mathrm{K}-12$, higher education, and adult education, 16th International Conference on Computers in Education, pp. 249-256.

[12] Chen, N., Wei, C., Kinshuk, Chen, Y. and Wang, Y. , (2008), 'Bridging the gap between face-to-face and cyber interaction in holistic blended learning environments', in H. Adelsberger, Kinshuk, J. Pawlowski, and D. Sampson (Eds.), 'Handbook on information technologies for education and training', pp 239-259.

[13] Sklar E. and Eguchi, A., (2004), 'Learning while teaching robotics', in Proceedings of AAAI Spring Symposium 2004 on Accessible Hands-on Artificial Intelligence and Robotics Education.

[14] Korchnoy, E. and Verner, I., (2010), 'Characteristics of learning computer-controlled mechanisms by teachers and students in a common laboratory environment', International journal of technology \& design education, Vol. 2, Issue 2, 2010, pp. 27-237.

[15] Yorita, A., Hashimoto, T., Kobayashi, H. and Kubota, N., (2009), 'Remote education based on robot edutainment', in Progress in robotics, Communications in 
computer and information science, Proceedings of FIRA RoboWorld Congress, J. Kim et al. (Eds.), Volume 44, pp. 204-213.

[16] Riojas, M., Lysecky, S. and Rozenblit, J., (2012), 'Educational technologies for precollege engineering education', IEEE Transactions on learning technologies, Volume:5, Issue:1, pp. 20 - 37.

[17] Hynes, M., (2012), 'Middle-school teachers' understanding and teaching of the engineering design process: a look at subject matter and pedagogical content knowledge', International journal of technology and design education, Volume 22, issue 3, pp. $345-360$.

[18] Howell, J. and McDonald, S., (2011), 'Creative technologies: bridging the gap in emerging literacy and numeracy', in Proceedings of INTED2011 Conference, Spain, pp. 3623-3631.

[19] Dias, A., Dias, N., Ferreira, H. and Campos, D., (2011), 'Standard commercial education robotic platform: intermediate solution to teaching robotics', in Proceedings of ICERI2011 Conference, Spain, pp. 1475-1482.

[20] VanLehn, K. and Chi, T., (1992), 'A model of the self-explanation effect', Journal of the learning sciences 2(1). Hillsdale, NJ: Lawrence Erlbaum Associates, pp. 159.

[21] Van Joolingen, W., (1999), 'Cognitive tools for discovering learning', International journal of artificial intelligence in education, pp. 385-397.

[22] Van Joolingen, W., (1995), 'Discovery learning with simulations and qualitative reasoning', AI-ED 95 Workshop, Wednesday, August 16th;

http://www.lri.jur.uva.nl/ winkels/qrile/jool.ps.gz,

(Access date: 14 September 2010).

[23] Alexopoulos, G., Koutsouris, A. and Tzouramani, I. , (2012), 'Adoption and use of ICTs among rural youth: evidence from Greece', in S. Chhabra (Ed.), 'ICTs for Advancing Rural Communities and Human Development: Addressing the Digital Divide', pp. 125-142.

[24] Reimann, P., (2008), 'Communities of practice', in H. Adelsberger, Kinshuk, J. Pawlowski, and D. Sampson (Eds.), 'Handbook on information technologies for education and training', pp 277-293.

[25] Tan, Q. and Kinshuk, (2009), "Client mobile software design principles for mobile learning systems", International journal of interactive mobile technologies (iJIM), Vol. 3, No 1, pp.32-37.

[26] Molnar, A. and Hava, C., (2012), 'Mobile learning: an economic approach', in S. Graf, F. Lin, Kinshuk, and R. McGreal (Eds.), "Intelligent and Adaptive Learning Systems: Technology Enhanced Support for Learners and Teachers", pp.311-326.

[27] Pau, R., Grace, M., Hall, W. and Woollard, J., (2011), 'Female students' experiences of programming: It's not all bad!', in Proceedings of the 16th annual joint conference on innovation and technology in computer science education, Germany, pp. 323-327.

[28] Vaillant, D, (2011), 'Preparing teachers for inclusive education in Latin America', Prospects, v.41, no.3, September, pp.385-398.

[29] Fundación Omar Dengo, (2010), 'Informe estadístico y de cobertura programa nacional de informática educativa MEP-FOD para preescolar, I, II y III ciclos, educación especial y aula abierta', Costa Rica; http://www.fod.ac.cr/pdf/informes/Informe_Estadistico_y_ Cobertura_del_PRONIE_MEP_\%28Dic_2010\%29.pdf (12 February 2012).

[30] Ministerio de Educación Pública, (2009), Infraestructura en el sistema educativo costarricense, Costa Rica.

[31] Ministerio de Educación Pública, (2010), Personal total que labora en instituciones de educación regular, Costa Rica.

[32] Fundación Quirós \& Tanzi, (2012), 'La brecha digital va más allá del acceso a una computadora: es una brecha de conocimiento'; http://www.fundacionqt.org/ (2 December 2012).

[33] Cronje, J., (2008), 'Lessons from Africa', in H. Adelsberger, Kinshuk, J. Pawlowski, and D. Sampson (Eds.), 'Handbook on information technologies for education and training', pp. 423-438. 